\title{
MENINGKATKAN PRESTASI BELAJAR IRISAN KERUCUT MELALUI MODEL DISCOVERY LEARNING
}

\author{
Eko Deslan Suprapti \\ SMAN 1 Pangkalpinang \\ ekosuprapti9@gmail.com
}

\begin{abstract}
Abstrak
Matematika merupakan mata pelajaran yang mempunyai implementasi yang tinggi terhadap mata pelajaran lainnya, seperti fisika, kimia, dan ekonomi. Tetapi kenyataannya hampir sebagian besar peserta didik mengikuti pelajaran matematika dengan perasaan terpaksa, mengantuk, membosankan, dan menganggap matematika suatu hal yang menakutkan, sehingga proses pembelajaran tidak maksimal dengan hasil belajar di bawah standar kriteria kelulusan, yakni pengetahuan $66,23=\mathrm{c}$; keterampilan 43,67 =d; dan sikap b. Dari kondisi dan suasana seperti di atas nampak bahwa motivasi untuk memahami dan keterampilan untuk menerapkan materi irisan kerucut dalam pemecahan masalah belum mencapai standar kriteria kelulusan minimum. Agar permasalahan dapat dipecahkan, maka peneliti atau guru perlu melakukan tindakan yaitu melakukan proses pembelajaran dengan model discovery learning agar dapat meningkatkan prestasi belajar irisan kerucut. Metode discovery learning adalah teori belajar yang didefinisikan sebagai proses pembelajaran yang terjadi bila peserta didik tidak disajikan dengan pelajaran dalam bentuk finalnya, tetapi diharapkan peserta didik mengorganisasi sendiri. Dalam mengaplikasikan metode discovery learning guru berperan sebagai pembimbing dengan memberikan kesempatan kepada peserta didik untuk belajar secara aktif, penelitian ini bertujuan untuk mengetahui sejauh mana model pembelajaran discovery learning dalam pelajaran irisan kerucut dapat meningkatkan prestasi belajar peserta didik kelas XI MIA 4 di SMAN 1 Pangkalpinang
\end{abstract}

Kata Kunci: Prestasi Belajar; Irisan Kerucut; dan Discovery Learning.

\section{Abstract}

Mathematics is a subject that has a high implementation of other subjects, such as physics, chemistry and economics. But the fact is that most of the students follow mathematics with compulsive feelings, are drowsy, are boring and consider mathematics a scary thing, so that the learning process is not maximized with learning outcomes under the graduation kriteria standards, namely knowledge $66.23=c$, skills $43.67=d$, and attitude b. From the conditions and atmosphere as above it appears that the motivation to understand and the skills for applying the material of cone slices in problem solving has not reached the minimum graduation kriteria standards. So that problems can be solved, the researcher or teacher needs to take action that is carrying out the learning process with the discovery learning model in order to improve the 


\section{Edutainment : Jurnal Ilmu Pendidikan dan Kependidikan}

Volume 8 Nomor 1 Edisi Januari - Juni 2020

learning performance of cone slices. The discovery learning method is a learning theory defined as a learning process that happens when students are not presented with lessons in their final form, but it is expected that students organize themselves. in applying the discovery learning method teachers act as a guide by providing opportunities to students to study active, this research aims to know to what extent the learning learning model in cone slice learning can improve student learning achievement class XI MIA 4 at SMAN 1 pangkalpinang.

Keywords: Academic Achievement, Conic Sections, and Discovery Learning.

\section{PENDAHULUAN}

Pada kurikulum 2013 mata pelajaran matematika dibagi menjadi dua kelompok, yakni matematika wajib dengan alokasi waktu 4 x 45 menit dalam satu minggu dan matematika peminatan $4 \times 45$ menit dalam satu minggu. Dengan standar kriteria kelulusan minimum pengetahuan 75 atau 2,66 $=\mathrm{B}$; keterampilan minimal 75 atau 2,66 $=\mathrm{B}$; dan sikap minimal B.

Matematika merupakan mata pelajaran yang mempunyai implementasi yang tinggi terhadap mata pelajaran lainnya, seperti fisika, kimia, dan ekonomi. Tetapi kenyataannya hampir sebagian besar peserta didik mengikuti pelajaran matematika dengan perasaan terpaksa, mengantuk, membosankan, dan menganggap matematika suatu hal yang menakutkan, sehingga proses pembelajaran tidak maksimal dengan hasil belajar di bawah standar kriteria kelulusan, yakni pengetahuan $66,23=\mathrm{C}$; keterampilan 43,67 = D; dan sikap B (rekap nilai 4 kelas tahun sebelumnya).
Dari kondisi dan suasana seperti di atas nampak bahwa motivasi untuk memahami dan keterampilan untuk menerapkan materi irisan kerucut dalam pemecahan masalah belum mencapai standar kriteria kelulusan minimum.

Ada beberapa hal yang menyebabkan kurangnya motivasi untuk memahami dan menerapkan keterampilan peserta didik terhadap pokok bahasan irisan kerucut sebagai berikut: 1) Irisan kerucut hampir seluruh materinya bersifat abstrak; 2) Memiliki bentuk bermacam-macam persamaan dan unsur-unsur, sehingga banyak terdapat rumus-rumus; 3) Pembelajaran cenderung satu arah dan monoton, membuat peserta didik bosan, pasif, dan pembelajaran menjadi kurang bermakna; 4) Penyelesaian masalah irisan kerucut mempunyai implementasi tinggi dengan cabang matematika lainnya, seperti Aljabar, Trigonometri, Geometri, dan Vektor.

Hal yang demikian menimbulkan kesulitan bagi peserta didik dalam memahami 


\section{Edutainment : Jurnal Ilmu Pendidikan dan Kependidikan}

Volume 8 Nomor 1 Edisi Januari - Juni 2020

materi ajar, sehingga kurang motivasi dan keputusasaan dalam mempelajarinya.

Agar permasalahan dapat dipecahkan, maka peneliti atau guru perlu melakukan tindakan yaitu melakukan proses pembelajaran dengan model discovery learning agar dapat meningkatkan prestasi belajar irisan kerucut.

Proses belajar mengajar merupakan proses yang mengandung serangkaian perbuatan guru dan peserta didik atas dasar hubungan timbal balik yang berlangsung dalam situasi edukatif untuk mencapai tujuan tertentu. Interaksi atau hubungan timbal balik antara peserta didik guru ini merupakan syarat utama bagi berlangsungnya proses belajar mengajar. Interaksi edukatif bukan hanya sekedar penyampaian materi pelajaran, melainkan penanaman sikap, motivasi diri, dan nilai peserta didik.

Strategi untuk memotivasi peserta didik dalam pembelajaran merupakan suatu kebutuhan bagi seorang pendidik untuk melaksanakan tugas pembelajaran yang sehat, kreatif, bermutu, meningkatkan kemampuan dasar peserta didik, dan mempercepat proses pembelajaran dengan hasil belajar maksimal (Wibawa, 2003).

Rumusan masalah penelitian ini sebagai berikut: Seberapa besar pencapaian model discovery learning dalam meningkatkan prestasi belajar peserta didik kelas XI MIA 4 di SMAN 1 Pangkalpinang?

Tujuan penelitian agar materi irisan kerucut tidak lagi menjadi pelajaran yang terlalu abstrak, sehingga dapat membuat peserta didik belajar aktif, bermakna, dan menyenangkan, serta ingin mengetahui seberapa besar pencapaian prestasi belajar peserta didik dengan model discovery learning di kelas XI MIA 4 SMAN 1 Pangkalpinang.

Menurut Djamarah (2004:20-21) dalam bukunya Prestasi Belajar dan Kompetensi Guru bahwa prestasi adalah apa yang telah dapat diciptakan, hasil pekerjaan, hasil yang menyenangkan hati yang diperoleh dengan jalan keuletan kerja. Dari pengertian di atas dapat diambil kesimpulan bahwa prestasi adalah hasil dari suatu kegiatan seseorang atau kelompok yang telah dikerjakan, diciptakan, dan menyenangkan hati yang diperoleh dengan jalan bekerja. Berdasarkan beberapa batasan di atas, prestasi belajar dapat diartikan sebagai kecakapan nyata yang dapat diukur yang berupa pengetahuan, sikap, dan keterampilan sebagai interaksi aktif antara subjek belajar dengan objek belajar selama berlangsungnya proses belajar mengajar untuk mencapai hasil belajar.

Irisan kerucut adalah materi geometri yang merupakan salah satu dari lima cabang 


\section{Edutainment : Jurnal Ilmu Pendidikan dan Kependidikan}

Volume 8 Nomor 1 Edisi Januari - Juni 2020

mata pelajaran matematika yang harus dikuasai oleh peserta didik kelas XI MIA dalam mata pelajaran kelompok B yaitu mata pelajaran matematika peminatan. Apollonius, matematikawan berkebangsaan Yunani, memberikan sumbangan kepada sejarah matematika dengan menyelidiki segala sifat penting dari sederetan lengkungan anggun yang digambarkan dalam sebuah bukunya yang berjudul irisan kerucut (sekitar 225 SM). Apollonius menyebutkan irisan kerucut karena ia membayangkannya sebagai irisan yang dibuat oleh bidang datar atau rata bila memotong permukaan sebuah kerucut ganda (kerucut dua sisi). Apollonius menyelidiki sifat masing-masing irisan kerucut dan memperlihatkan bahwa sifat-sifat ini saling berkaitan. Sebagai matematika murni, sesungguhnya semua jerih payah yang penuh akal ini pembenaran, tetapi ternyata fakta menunjukkan bahwa irisan kerucut merupakan lintasan yang diikuti oleh rudal, satelit, bulan atau bumi, karena pengaruh gaya berat di sekeliling planet atau bintang (Tim Penyusun, 2003:30).

Jika sebuah kerucut atau kerucut ganda dipotong oleh sebuah bidang datar, maka akan terjadi bangun-bangun geometri yang disebut irisan kerucut. Seperti kita membayangkan saat kita memotong kerucut es krim dengan pisau tajam. Bangun geometri yang terjadi tergantung cara mengirisnya, hasil akan berupa lingkaran, parabola, hiperbola, dan ellips yang banyak sekali sifat-sifat, aturan aturan, rumus-rumus, dan unsur-unsur yang abstrak (Hanafiah, 1992).

Metode discovery learning adalah teori belajar yang didefinisikan sebagai proses pembelajaran yang terjadi bila pelajar tidak disajikan dengan pelajaran dalam bentuk finalnya, tetapi diharapkan peserta didik mengorganisasi sendiri. Sebagai strategi belajar, discovery learning mempunyai prinsip yang sama dengan inkuiri (inquiry) dan problem solving. Tidak ada perbedaan yang prinsipil pada ketiga istilah ini, pada discovery learning lebih menekankan pada ditemukannya konsep atau prinsip yang sebelumnya tidak diketahui. Perbedaannya dengan discovery ialah pada discovery masalah yang diperhadapkan kepada peserta didik semacam masalah yang direkayasa oleh guru. Dalam mengaplikasikan metode discovery learning guru berperan sebagai pembimbing dengan memberikan kesempatan kepada peserta didik untuk belajar secara aktif, sebagaimana pendapat guru harus dapat membimbing dan mengarahkan kegiatan belajar peserta didik sesuai dengan tujuan. Kondisi seperti ini ingin merubah kegiatan belajar mengajar yang teacher oriented menjadi student oriented. Dalam discovery 


\section{Edutainment : Jurnal Ilmu Pendidikan dan Kependidikan}

Volume 8 Nomor 1 Edisi Januari - Juni 2020

learning, hendaknya guru harus memberikan kesempatan muridnya untuk menjadi seorang problem solver, seorang scientis, atau ahli matematika. Bahan ajar tidak disajikan dalam bentuk akhir, tetapi peserta didik dituntut untuk melakukan berbagai kegiatan menghimpun informasi, membandingkan, mengkategorikan, menganalisis, mengintegrasikan, mengorganisasikan bahan, serta membuat kesimpulan-kesimpulan (Fatimah, 2008).

\section{Keuntungan discovery learning} (Kemendikbud, 2013:91) sebagai berikut: 1) Membantu peserta didik untuk memperbaiki dan meningkatkan keterampilan-keterampilan dan proses-proses kognitif. Usaha penemuan merupakan kunci dalam proses ini, seseorang tergantung bagaimana cara belajarnya. Pengetahuan yang diperoleh melalui metode ini sangat pribadi dan ampuh, karena menguatkan pengertian, ingatan, dan transfer.

2) Menimbulkan rasa senang pada peserta didik, karena tumbuhnya rasa menyelidiki dan berhasil. 3) Metode ini memungkinkan peserta didik berkembang dengan cepat dan sesuai dengan kecepatannya sendiri. 4) Menyebabkan peserta didik mengarahkan kegiatan belajarnya sendiri dengan melibatkan akalnya dan motivasi sendiri. 5) Metode ini dapat membantu peserta didik memperkuat konsep dirinya, karena memperoleh kepercayaan bekerja sama dengan yang lainnya. 6) Berpusat pada peserta didik dan guru berperan sama-sama aktif mengeluarkan gagasan-gagasan. Bahkan gurupun dapat bertindak sebagai peserta didik, dan sebagai peneliti di dalam situasi diskusi. 7) Membantu peserta didik menghilangkan skeptisme (keragu-raguan), karena mengarah pada kebenaran yang final dan tertentu atau pasti. 8) Peserta didik akan mengerti konsep dasar dan ide-ide lebih baik. 9) Membantu dan mengembangkan ingatan dan transfer kepada situasi proses belajar yang baru. 10) Mendorong peserta didik berfikir dan bekerja atas inisiatif sendiri. 11) Mendorong peserta didik berfikir intuisi dan merumuskan hipotesis sendiri. 12) Memberikan keputusan yang bersifat intrinsik. Situasi proses belajar menjadi lebih terangsang. 13) Proses belajar meliputi sesama aspeknya peserta didik menuju pada pembentukan manusia seutuhnya. 14) Meningkatkan tingkat penghargaan pada peserta didik. 15) Kemungkinan peserta didik belajar dengan memanfaatkan berbagai jenis sumber belajar. 16) Dapat mengembangkan bakat dan kecakapan individu.

Kelemahan discovery learning (Depdikbud, 2014:92) sebagai berikut: 1) Metode ini menimbulkan asumsi bahwa ada kesiapan pikiran untuk belajar. Bagi peserta 


\section{Edutainment : Jurnal Ilmu Pendidikan dan Kependidikan}

Volume 8 Nomor 1 Edisi Januari - Juni 2020

didik yang kurang pandai, akan mengalami kesulitan abstrak atau berfikir atau mengungkapkan hubungan antara konsepkonsep yang tertulis atau lisan, sehingga pada gilirannya akan menimbulkan frustasi. 2) Metode ini tidak efisien untuk mengajar jumlah peserta didik yang banyak, karena membutuhkan waktu yang lama untuk membantu mereka menemukan teori atau pemecahan masalah lainnya. 3) Harapanharapan yang terkandung dalam metode ini dapat buyar berhadapan dengan peserta didik dan guru yang telah terbiasa dengan cara-cara belajar yang lama. 4) Pengajaran discovery learning lebih cocok untuk mengembangkan pemahaman, sedangkan mengembangkan aspek konsep, keterampilan, dan emosi secara keseluruhan kurang mendapat perhatian. 5) Pada beberapa disiplin ilmu, misalnya IPA kurang fasilitas untuk mengukur gagasan yang dikemukakan oleh para peserta didik. 6) Tidak menyediakan kesempatan-kesempatan untuk berfikir yang akan ditemukan oleh peserta didik, karena telah dipilih terlebih dahulu oleh guru.

Langkah-langkah operasional discovery learning menurut Syah (2004:244) dalam mengaplikasikan metode discovery learning di kelas, ada beberapa prosedur yang harus dilaksanakan dalam kegiatan belajar mengajar secara umum sebagai berikut: a)
Stimulation (stimulasi/pemberian rangsangan); b) Problem statement (pernyataan/ identifikasi masalah); c) Data collection (Pengumpulan Data); d) Data processing (Pengolahan Data); e) Verification (Pembuktian); f) generalization (menarik kesimpulan/generalisasi); dan e) Sistem penilaian.

Dalam model pembelajaran discovery learning, penilaian dapat dilakukan dengan menggunakan tes maupun non tes. Penilaian yang digunakan dapat berupa penilaian kognitif, proses, sikap, atau penilaian hasil kerja Peserta didik. Jika bentuk penilainnya berupa penilaian kognitif, maka dalam model pembelajaran discovery learning dapat menggunakan tes tertulis. Jika bentuk penilaiannya menggunakan penilaian proses, sikap atau penilaian hasil kerja peserta didik, maka pelaksanaan penilaian dapat dilakukan dengan pengamatan (Kemendikbud, 2014).

\section{METODOLOGI PENELITIAN}

Metode yang digunakan dalam penelitian ini yaitu research and action, yakni penelitian dan tindakan untuk mengatasi masalah-masalah yang terjadi di dalam kelas kita.

Penelitian dilaksanakan di SMAN 1 Pangkalpinang pada kelas XI MIA 4 dengan jumlah peserta didik 30 orang yang terdiri dari 12 orang peserta didik laki-laki, dan 18 orang 


\section{Edutainment : Jurnal Ilmu Pendidikan dan Kependidikan}

Volume 8 Nomor 1 Edisi Januari - Juni 2020

peserta didik perempuan. Alasan pemilihan kelas ini dikarenakan jumlah peserta didik laki-laki dan perempuan yang relatif seimbang serta hasil pretest pada pertemuan pertama hasil belajar di bawah standar kriteria kelulusan yaitu pengetahuan 66,23 = B-; keterampilan 43,67 = D; dan sikap B.

Sumber data pada penelitian ini berasal dari hasil pengamatan peneliti selama melaksanakan kegiatan mengajar. Kesulitan utama yang ditemui pada saat peserta didik menerapkan konsep, aturan, sifat, dan rumusrumus irisan kerucut dalam menyelesaikan masalah. Begitu juga dengan peserta yang dijadikan subjek penelitian ini, penguasaan kompetensi dasar di bawah 75.

Pengamatan, penilaian pada tahap ini yaitu dengan melakukan pengamatan langsung kepada peserta didik. Tujuan penilaian ini untuk mengetahui bagaimana bisa terjadi peningkatan prestasi belajar dalam aspek sikap, pengetahuan, dan keterampilan peserta didik. Observasi terhadap kelas dan keterlaksanaan pembelajaran dilakukan oleh 3 orang, 2 teman sejawat dan 1 pengawas dinas kota Pangkalpinang, yakni guru-guru SMAN 1 Pangkalpinang yaitu Dra. Rosi Martini, Drs. Rachmad, M.M. dan innayahturomah, S.Pd. Kegiatan observasi dilakukan dengan menggunakan format atau daftar observasi sikap dan keterampilan. Pengamatan dilakukan untuk mendapatkan nilai attitude (sikap) dan skills (keterampilan) peserta didik. Tes unjuk kerja yaitu untuk mengetahui kemampuan peserta didik dalam mencapai tingkat kompetensi yang diharapkan dalam hal ini penilaian unjuk kerja dalam menyelesaikan tes keterampilan. Kegiatan pada tahap ini diawali dengan membuat instrumen tes unjuk kerja. Inti kegiatan yang akan dilakukan yaitu dengan melakukan pengamatan terhadap unjuk kerja peserta didik dalam menyelesaikan tes keterampilan digunakan untuk memperoleh nilai keterampilan peserta didik.

Jenis tes tulis terdiri dari tes bentuk objektif dan bentuk uraian atau esai berstruktur. Tes uraian atau tes esai berstruktur sifatnya lebih kompleks dari pada tes objektif. Tes ini menuntut kemampuan berpikir dan bernalar dan pada akhirnya tes ini akan memperoleh nilai knowledge (pengetahuan / kognitif).

Tes lisan diperlukan untuk tujuan mengungkapkan atau memperoleh lebih lanjut tentang hal-hal yang dirasa kurang jelas informasinya oleh pendidik. Tes lisan ini juga digunakan untuk sebagai alat menelusuri kesukaran yang dialami peserta didik. Pada penelitian ini tes lisan digunakan untuk 


\section{Edutainment : Jurnal Ilmu Pendidikan dan Kependidikan}

Volume 8 Nomor 1 Edisi Januari - Juni 2020

memperoleh masukan tentang knowledge (pengetahuan / kognitif) (Arikunto, 2007).

Sedangkan untuk memperoleh hasil, pada penelitian ini menggunakan format atau instrumen berupa: 1) Daftar observasi unjuk kerja, 2) Format tes tulis, 3) Format tes lisan, 4) Format penilaian diri. Validasi data diperlukan untuk memperoleh data yang valid. Validitas yang digunakan perlu disesuaikan dengan data yang dikumpulkan. Data kualitatif berupa observasi divalidasi berupa triangulasi sumber yaitu melalui kolaborasi dengan teman sejawat. Data kuantitatif (berbentuk angka) yang divalidasi yaitu instrumennya. Analisa data pada penelitian ini disesuaikan dengan metode dan jenis data yang dikumpulkan dalam hal ini yaitu hasil evaluasi, hasil observasi, dan hasil penilaian diri. Analisa dalam penelitian tindakan kelas ini menggunakan deskriptif. Data Kuatitatif menggunakan analisis deskriptif komparatif yaitu dengan membandingkan tingkat pencapaian kompetensi kondisi awal, tingkat pencapaian kompetensi siklus 1, tingkat pencapaian kompetensi siklus 2, dan kemudian direfleksi. Data kualitatif hasil pengamatan maupun lisan menggunakan analisis deskriptif kualitatif berdasarkan hasil observasi dan refleksi dari setiap siklus pada penelitian tindakan kelas ini.
Prosedur penelitian diuraikan berupa langkah-langkah sebagai berikut: 1) Menentukan metode yang digunakan dalam penelitian yaitu menggunakan metode Penelitian Tindakan Kelas; 2) Menentukan banyaknya tindakan yang dilakukan dalam siklus dalam hal ini dua siklus; 3) Menentukan tahapan-tahapan dalam siklus terdiri dari empat tahapan, yakni perencanaan, pelaksanaan, observasi, dan refleksi. Pelaksanaan tindakan yang meliputi siapa melakukan apa, kapan, dimana, dan bagaimana melakukannya RPP tindakan yang telah direncanakan, dilaksanakan dalam situasi yang aktual. Pada saat bersamaan kegiatan ini juga disertai dengan observasi dan interpretasi serta diikuti dengan kegiatan refleksi (Kasbolah, 1999).

\section{HASIL DAN PEMBAHASAN}

\section{Hasil}

Siklus 1: Setelah pelaksanaan penelitian tindakan kelas ini, peneliti bersama observer mengadakan refleksi. Dari hasil siklus 1 ditemukan hal-hal yang perlu diperbaiki, yaitu mengenai keterlaksanaan prosedur pembelajaran oleh peserta didik. Pada kegiatan inti fase identifikasi masalah atau problem statement, peserta didik sudah bisa menemukan bidang-bidang irisan kerucut, tetapi belum fokus dalam pembahasan konsep, sifat-sifat, grafik, dan persamaan parabola 


\section{Edutainment : Jurnal Ilmu Pendidikan dan Kependidikan}

Volume 8 Nomor 1 Edisi Januari - Juni 2020

irisan kerucut. Peserta didik masih kelihatan bingung antara persamaan parabola, fungsi parabola, dan persamaan parabola irisan kerucut. Pada fase pembuktian atau verifikasi kelompok pertama belum mampu menemukan konsep parabola oleh kelompok lain, kemudian dipertegas melalui persamaan parabola dan sketsa grafik parabola sederhana. Agar lebih jelas lembar kerja peserta didik (LKS) dapat disusun lebih terinci, terbimbing, dan menarik, agar peserta didik akan lebih termotivasi, sehingga akan lebih mudah untuk membimbing peserta didik mengumpulkan dan mengolah data untuk membuktikan hipotesisnya. Temuan-temuan pada siklus 1 ini akan ditindaklanjuti pada siklus 2 .

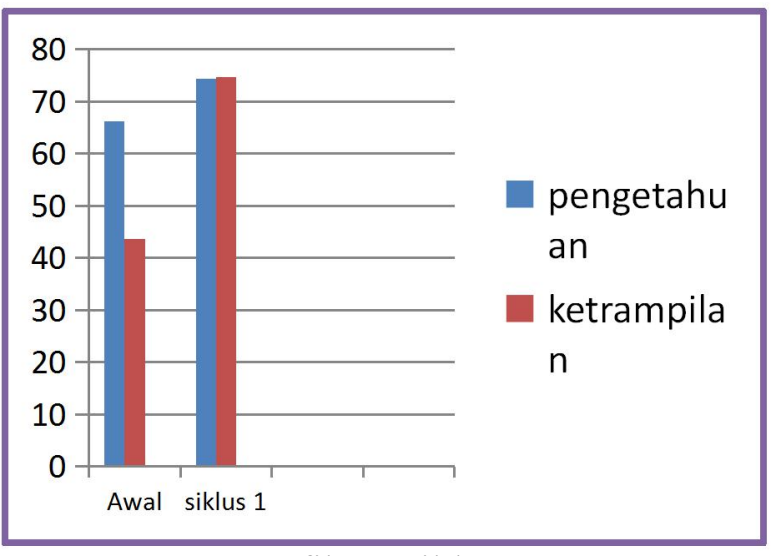

Grafik 1. Siklus 1

Dari daftar nilai di atas menunjukkan

hasil pengetahuan, keterampilan, dan sikap peserta didik bahwa ada peningkatan nilai peserta didik dari keadaan awal, dari pengetahuan 66,23 menjadi 74,33 atau dari predikat B- menjadi B, keterampilan dari 43,67 menjadi 74,67 atau dari $\mathrm{C}$ menjadi $\mathrm{B}$, dan sikap tetap B. Penggunaan model pembelajaran discovery learning pada kegiatan pembelajaran siklus 1 dapat meningkatkan nilai pengetahuan dan keterampilan, tetapi untuk pengetahuan belum mencapai KKM yaitu $75=\mathrm{B}+$, maka akan ditindaklanjuti di siklus 2 dengan memperbaiki RPP dan LKS yang lebih terinci dan terbimbing.

Siklus 2: Setelah selesai kegiatan pada siklus dua ini, peneliti bersama observer melakukan refleksi dari hasil pengamatan. Pada siklus dua ini ada peningkatan dan perbaikan, penelitian ini sudah memenuhi kriteria ketuntasan yang diharapkan, yakni dari siklus 1 nilai pengetahuan $74,33=\mathrm{B}$; pada siklus 2 menjadi $84,81=\mathrm{B}+$; dan nilai keterampilan dari $74,67=\mathrm{B}$ pada siklus 2 menjadi $89=\mathrm{A}-$.

Pada kegiatan siklus kedua lembar pengamatan sama, hanya pada siklus kedua lebih menekankan pada kegiatan peserta didiknya, sebab ingin peserta didik lebih fokus pada langkah-langkah pada lembar kerjanya. Terlihat adanya kemajuan dalam mengumpulkan data dan mengolah data. Presentasi jadi lebih lancar dan terarah kepada tujuan pembelajaran. Nampak para peserta didik aktif dalam menyampaikan pendapat dan pembelajaran menjadi bermakna. 
Dari hasil pelaksanaan penelitian siklus 2 ini dapat dilihat dalam grafik di bawah ini:

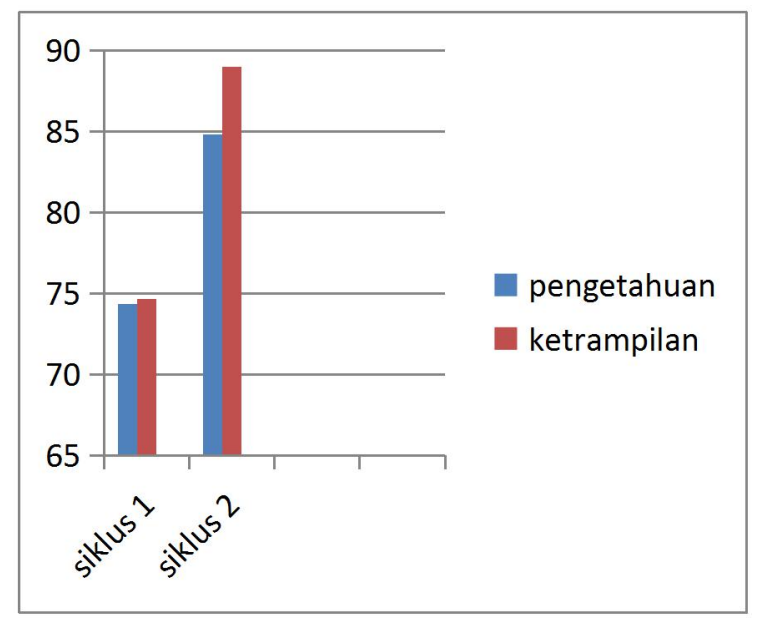

Grafik 2. Perbandingan Nilai Siklus 1 dan Siklus 2

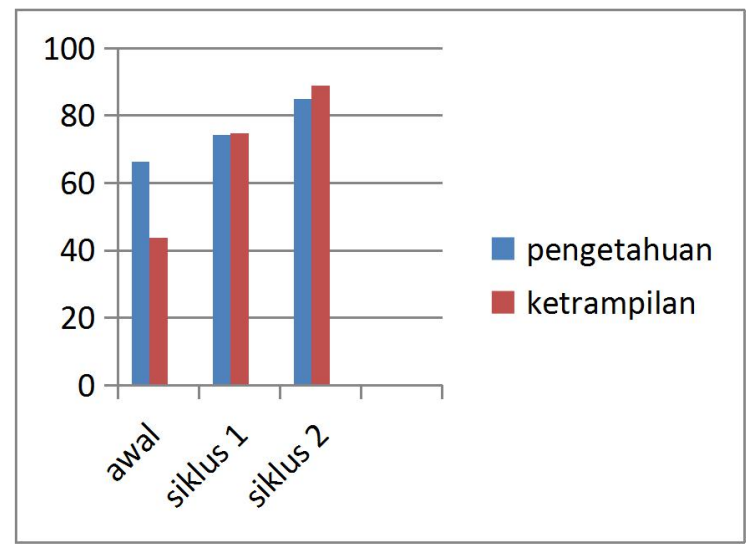

Grafik 3. Perbandingan Nilai Kondisi Awal, Siklus 1 dan Siklus 2

Grafik di atas dapat menunjukkan tentang persentase belajar peserta didik dalam kegiatan pembelajaran di kelas melalui kegiatan penelitian tindakan kelas yang diawali melalui sebelum adanya solusi dalam permasalahan yang dihadapi yaitu mengenai peningkatan prestasi belajar irisan kerucut.
Kemudian setelah itu diadakan penelitian tindakan kelas melalui tahap siklus 1 dan 2 .

Pada awal sebelum diadakan penelitian tindakan kelas menunjukkan prestasi belajar peserta didik dalam irisan kerucut untuk aspek pengetahuan hanya 66,23 $=$ B- dan keterampilan 43,67 =C, kemudian setelah diadakan penelitian dengan menggunakan solusi metode scientific dengan model discovery learning dan media LKS, pada siklus pertama meningkat menjadi 74,33 $=\mathrm{B}$ untuk pengetahuan dan $74,67=\mathrm{B}$ untuk keterampilan, sementara pada siklus kedua $84,81=\mathrm{B}+$ untuk pengetahuan dan $89=\mathrm{A}-$ untuk keterampilan. Besar peningkatan kompetensi pengetahuan sebesar 84,81 $66,23=\frac{16,58}{100} \times 100 \%=16,58 \%$ dan kompetensi keterampilan sebesar 89,00 $43,67=\frac{45,33}{100} x 100 \%=45,33 \%$.

\section{Pembahasan}

Sebelum diadakannya solusi pemecahan masalah yang dihadapi yaitu mengenai kurangnya minat peserta didik, sehingga kurang motivasi dalam belajar yang disebabkan oleh: 1) Irisan kerucut hampir seluruh materinya bersifat abstrak; 2) Memiliki bentuk persamaan yang bermacammacam, sehingga banyak terdapat rumusrumus; 3) Pembelajaran cenderung satu arah dan monoton; 4) Penyelesaian masalah irisan kerucut mempunyai implementasi tinggi 


\section{Edutainment : Jurnal Ilmu Pendidikan dan Kependidikan}

Volume 8 Nomor 1 Edisi Januari - Juni 2020

dengan cabang matematika lainnya, seperti Aljabar, Trigonometri, Geometri dan Vektor.

Hal yang demikian menimbulkan kesulitan bagi peserta didik dalam memahami materi ajar, sehingga kurang motivasi dan keputusasaan dalam mempelajarinya.

Agar permasalahan dapat dipecahkan, maka peneliti atau guru perlu melakukan tindakan yaitu melakukan proses pembelajaran dengan model discovery learning agar dapat meningkatkan prestasi belajar irisan kerucut.

\section{Pembahasan Siklus 1}

Pada semua tahapan siklus 1 tim peneliti yang terdiri dari peneliti dan dua orang observer menganalisa bahwa: a) Peserta didik sudah menunjukkan semangat ingin belajar, karena mereka tidak lagi mengantuk dan ngobrol pada saat pembelajaran; b) Peserta didik cukup aktif dalam tanya jawab; c) Kerja sama dalam kelompok belum maksimal, karena masih ada yang bingung dalam mengumpulkan dan mengolah data untuk menentukan hipotesis awal; d) Kemampuan memberikan ide dan penyelesaian masalah dalam presentasi belum maksimal, karena hanya dimonopoli oleh beberapa peserta didik itu-itu saja; e) Dari hasil pengamatan dan pembahasan tim peneliti, dimana motivasi anak dalam pembelajaran tersebut belum maksimal, maka penelitian dilanjutkan dengan siklus 2 .

\section{Pembahasan Siklus 2}

Pada siklus 2 ini, peneliti dalam tahap perencanaan memperbaiki langkah-langkah LKS, agar peserta didik lebih terarah dan terbimbing dalam mengumpulkan dan mengolah data, sehingga mendukung hipotesis awal. Dalam fase pembuktian atau verifikasi. Peserta didik dapat menarik kesimpulan yang menjadi tujuan pembelajarannya.

Sampai tahap refleksi pada siklus 2 ini, semua yang belum maksimal pada siklus 1 dapat dimaksimalkan dengan baik. Penelitian ini dapat menunjukkan bahwa peserta didik dalam belajar perlu stimulus atau rangsangan, sehingga membuat mereka termotivasi untuk menggali kompetensi awal yang mereka miliki dan dibantu dengan fase-fase belajar yang ilmiah yang didukung oleh media pembelajaran yang tepat dalam hal ini yaitu LKS.

\section{SIMPULAN DAN SARAN}

\section{Simpulan}

Model pembelajaran discovery learning dapat membantu: 1) Peserta didik menemukan konsep matematika khususnya irisan kerucut yang memiliki banyak rumusrumus bersifat abstrak dapat ditemukan 


\section{Edutainment : Jurnal Ilmu Pendidikan dan Kependidikan}

Volume 8 Nomor 1 Edisi Januari - Juni 2020

menjadi lebih konkret dengan cara melukis skets grafiknya; 2) Memotivasi peserta didik belajar kreatif dan bermakna; 3) Meningkatkan prestasi belajar peserta didik kelas XI MIA 4 terhadap pembelajaran materi irisan kerucut di SMAN 1 Pangkalpinang Bangka Belitung sebesar 16,58\% untuk kompetensi pengetahuan dan 45,33 \% kompetensi keterampilan; 4) Tenaga pendidik mengelola kelas dalam proses kegiatan pembelajaran yang inovatif, kreatif, menarik, sehingga pembelajaran menjadi bermakna

\section{Saran}

Adapun saran dari hasil penelitian ini, yakni: 1) Untuk membuat kegiatan belajar mengajar menjadi bermakna tenaga pendidik harus kreatif memilih model pembelajaran yang sesuai dengan karakter materi pelajaran dan peserta didiknya. 2) Jika menghadapi masalah dalam kegiatan belajar mengajar di kelas, diskusikan bersama MGMP sekolah, dan cari solusinya dengan penelitian tindakan kelas.

\section{DAFTAR PUSTAKA}

Arikunto, S. (2007). Penelitian Tindakan Kelas. Bandung: Bumi Aksara.

Djamarah, S. B. (2004). Prestasi Belajar dan Kompetensi Guru. Surabaya: Usaha Nasional.

Fatimah, S. (2008). Model-model Pembelajaran Pendidikan dan Pelatihan Guru Rayon 4. Palembang: Unsri.

Hanafiah, D. (1992). Geometri. Bandung: Pakar Raya.

Kasbolah, K. (1999). Penelitian Tindakan Kelas. Jakarta: Depdikbud.

Kemendikbud. (2013). Implementasi Kurikulum 2013. Jakarta: Kementerian Pendidikan dan Kebudayaan.

Kemendikbud. (2014). Materi Pelatihan Implementasi Kurikulum 2013. Jakarta: Kementerian Pendidikan dan Kebudayaan.

Syah, M. (2004). Psikologi Pendidikan Suatu Pendekatan Baru. Bandung: PT Remaja Rosdakarya.

Tim Penyusun. (2003). Matematika 3a. Klaten: Intan Pariwara.

Wibawa, Basuki. 2003. Penelitian Tindakan Kelas. Jakarta: Depdiknas. 